\title{
Tectonic wedging along the rear of the offshore Taiwan accretionary prism
}

\author{
Wu-Cheng Chi ${ }^{\mathrm{a}, \mathrm{b}, *}$, Donald L. Reed ${ }^{\mathrm{a}}$, Greg Moore $^{\mathrm{c}}$, Tuan Nguyen ${ }^{\mathrm{b}}$, \\ Char-Shine Liu ${ }^{\mathrm{d}}$, Neil Lundberg ${ }^{\mathrm{e}}$ \\ a Department of Geology, San Jose State University, San Jose, CA 95192-0102, USA \\ ${ }^{\mathrm{b}}$ Department of Earth and Planetary Science, University of California, Berkeley, CA 94720, USA \\ ${ }^{\mathrm{c}}$ Department of Geology and Geophysics, SOEST, University of Hawaii, Hawaii, HI 96822, USA \\ ${ }^{\mathrm{d}}$ Institute of Oceanography, National Taiwan University, Taipei, Taiwan, ROC \\ ${ }^{\mathrm{e}}$ Department of Geology, Florida State University, Tallahassee, FL 08544, USA
}

Received 2 November 2001; accepted 11 August 2003

\begin{abstract}
The structural geometry, kinematics and density structure along the rear of the offshore Taiwan accretionary prism were studied using seismic reflection profiling and gravity modeling. Deformation between the offshore prism and forearc basin at the point of incipient collision, and southward into the region of subduction, has been interpreted as a tectonic wedge, similar to those observed along the front of mountain ranges. This tectonic wedge is bounded by an east-dipping roof thrust and a blind, west-dipping floor thrust. An east-dipping sequence of forearc-basin strata in the hanging wall of the roof thrust reaches a thickness in excess of $4 \mathrm{~km}$ near the tip of the interpreted tectonic wedge. Section restoration of the roof sequence yields an estimate of $4 \mathrm{~km}$ of shortening, which is small compared with that inferred in the collision area to the north, based on the variation in distance between the apex of the prism and the island arc.

Previous studies propose that either high-angle normal faulting or backfolding has exhumed the metamorphic rocks along the eastern flank of the Central Range in the collision zone on land. To better constrain the initial crustal configuration, we tested 350 crustal models to fit the free-air gravity anomaly data in the offshore region to study the density structure along the rear of the accretionary prism in the subduction and initial collision zones before the structures become more complex in the collision zone on land. The gravity anomaly, observed in the region of subduction $\left(20.2^{\circ} \mathrm{N}\right)$, can be modeled with the arc basement forming a trenchward-dipping backstop that is overlain by materials with densities in the range of sedimentary rocks. Near the point of incipient collision $\left(20.9^{\circ} \mathrm{N}\right)$, however, the free-air gravity anomaly over the rear of the prism is approximately 40 mgal higher, compared with the region of subduction, and requires a significant component of high density crustal rocks within the tectonic wedge. These results suggest that the forearc basement may be deformed along the rear of the prism, associated with the onset of collision, but not in the subduction region further to the south.
\end{abstract}

(C) 2003 Elsevier B.V. All rights reserved.

Keywords: Tectonic wedge; Lithospheric collision; Seismic reflection data; Gravity modeling

\footnotetext{
* Corresponding author. Present address: Department of Earth and Planetary Science, University of California, Berkeley, CA 94720, USA. Fax: +1-510-643-9980.

E-mail address: chi@seismo.berkeley.edu (W.-C. Chi).
} 


\section{Introduction}

A tectonic wedge (Wentworth et al., 1984) is a wedge-shaped structure bounded by a roof thrust along its upper surface and a floor thrust beneath (Fig. 1). Tectonic wedges have been recognized in a number of regions, including the California Coast Ranges (Wentworth et al., 1984; Unruh et al., 1995; Wakabayashi and Unruh, 1995; Jachens et al., 1995), the Rocky Mountain front (Lawton et al., 1996), and Himalayan orogen (Jadoon and Frisch, 1997). The floor thrust is buried under the tectonic wedge and commonly occurs as a blind thrust that is difficult to map based on surface observations. The hanging wall of the roof thrust (roof sequence) can be composed of a dipping sequence of thick basin sediments. Backthrusting in the form of tectonic wedging has been identified along the rear of several submarine accretionary prisms and thrust belts (Westbrook et al., 1988; Silver and Reed, 1988; Torrini and Speed, 1989; Silver et al., 1990; Reed and Silver, 1995). To avoid confusion, in this article we use "wedge" to indicate tectonic wedge and "prism" to indicate accretionary prism. In addition to their tectonic significance, these features can form structural traps for petroleum and may also be seismogenic (Wentworth et al., 1984).

Deformation along the rear of the offshore Taiwan accretionary prism in the region of subduction has also been interpreted as a tectonic wedge (Reed et al., 1992; Lundberg, 1992; Lundberg et al., 1997). There are two competing models that have been used to explain deformation further to the north, along the eastern flank of the Taiwan Central Range, which lies in an analogous position as the rear of the offshore prism. One model has proposed two parallel, steeply dipping normal faults that allow uplift and exhumation of high to medium-grade metamorphic rocks of continental origin in the Central Range (Crespi et al., 1996; Byrne and Crepsi, 1997a; Lin et al., 1998). This feature may project southwards along the east coast of the Hengchun peninsula and into the offshore along the eastern flank of the submarine Hengchun Ridge, which forms the rear of the accretionary prism. On the other hand, Fisher and Willett (1998) proposed that backfolding within a double-vergent orogen above a west (trenchward)-dipping back stop may explain the onland structures in a manner that is similar to the backthrusting model interpreted for the offshore. Strike-slip faulting is also active in the Longitudinal Valley and offshore, but cannot by itself account for the large amounts of uplift in both regions. On land deformation may also be complicated by the incoming thick passive margin, but a reliable geodynamic model in the offshore region where the structures are simpler may help constrain the initial models for the arccontinent collision zone. The major difference between these models is the nature of deformation along the eastern flank of the Central Range, high-angle normal faulting or backfolding associated with thrusting, and the geometry of the arc basement, which acts as a backstop against which deformation takes place. In this study we use geophysical data to better constrain the deformation style in the offshore region, and to examine the involvement of the forearc basement along the rear of the prism.

Here we use migrated multichannel depth sections and gravity modeling to examine the geometry and kinematics of deformation along the rear of the prism in the offshore, near the region of incipient collision, and southwards to the region of subduction. Multichannel data are first used to interpret deformation in this region as reflecting a tectonic wedge related to compression due to crustal shortening. Next, we show that, in the subduction zone, the shortening at shallow depth along the rear of the prism is small, compared to that observed to the north along the Taitung Trough where arc-continent collision began 1-2 Ma. Finally, we provide constraints on the nature of the basement (backstop) geometry in the regions of subduction and the earliest phases of arc-continent collision. At the very least, we determine whether or not basement rocks (or the backstop) are involved in the deformation at this point. The results of gravity modeling are consistent with a tectonic wedge composed mainly of sedimentary material at the latitude of $20.2^{\circ} \mathrm{N}$, which overlies the west-dipping basement of the island arc, while at $20.9^{\circ} \mathrm{N}$, the in-situ or underplated basement rocks may become involved in deformation and uplifted. This interpretation implies that the sedimentary materials within the tectonic wedge must be part of the accretionary prism or have been incorporated into the tectonic wedge by duplexing of forearc basin strata above a trenchward dipping backstop in the subduction region. As the subduction changes into collision, however, high density materials associated 


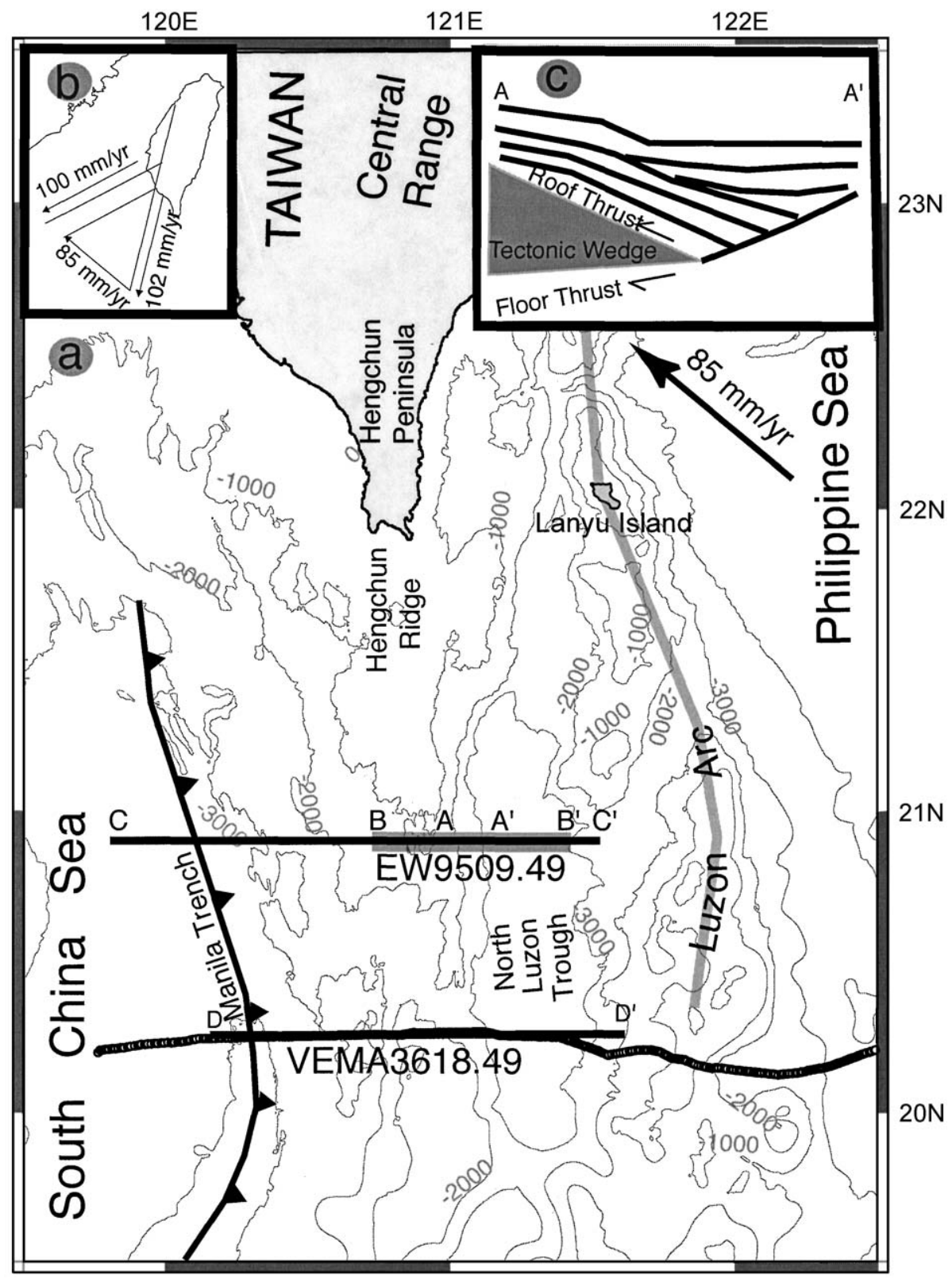

Fig. 1. (a) Location map. Lithosphere beneath the South China Sea is subducting southeastward at a rate of $85 \mathrm{~mm} /$ year under the Philippine Sea plate along Manila Trench. The thick gray line marks the location of line EW9509.49 crossing the initial arc-continent collision region. Line $\mathrm{AA}^{\prime}$ marks the location for a seismic profile in Fig. 2. Line BB' marks the location for Fig. 7. Line $\mathrm{CC}^{\prime}$ marks the location for Fig. 6. Line DD' marks the location for Fig. 9. Circles mark the line V3618.49 collected by R/V Vema crossing the subduction zone. An example of the upper and lower slope domains and the backthrust domain is shown in Fig. 9. (b) Due to the oblique angle of the Chinese Passive Margin with respect to the trench, the collision is currently propagating southward along the trench at a rate of $102 \mathrm{~mm} /$ year (Lundberg et al., 1997). (c) A cartoon showing a tectonic wedge bounded by a roof thrust along the top and a floor thrust at the bottom. The location of the schematic tectonic wedge profile is marked by $\mathrm{AA}^{\prime}$ in the regional map. 
with the forearc basement, are deformed, possibly in a mode that is compatible with the double vergent orogen model (Willett and Hovius, 1998; Fisher and Willett, 1998; Malavieille et al., in press).

\section{Tectonic setting}

The Taiwan collision zone is located along the boundary between the Eurasian plate and Philippine Sea plate where the Chinese continental margin has been juxtaposed with the northern segment of Luzon island arc (Bowin et al., 1978). South of the island, oceanic lithosphere of the South China Sea is subducting eastward beneath the Philippine Sea plate along the Manila Trench (Fig. 1) (Bowin et al., 1978; Taylor and Hayes, 1980).

The initial collision probably began in the late middle Miocene (Teng, 1990) and is currently propagating southward at a rate of 55 to $120 \mathrm{~mm} /$ year (Lundberg et al., 1997; Byrne and Crepsi, 1997b; Suppe, 1984). The geometry of the plate boundary, plate motion, and continental-ocean boundary in the Eurasian plate produces a southward propagation of the collision, allowing the concept of time-space equivalence to be applied to the evolution of the collision complex (Suppe, 1984). This concept states that evolution of the collision can be studied by constructing a series of cross sections, oriented east-west, through the subduction zone in the south to the more mature collision zone on Taiwan in the north. However, this concept remains controversial. Malavieille et al. (in press) has proposed that the deformation of the accreted arc terminated abruptly just south of Taiwan. Based on 2D and 3D physical modeling, Chemenda et al. (2001) also proposed that the Longitudinal Valley Fault, a major structure in Taiwan, is propagating to the south.

Recent kinematic studies of Taiwan island have greatly improved the understanding of deformation at shallow depths of the collision complex (e.g. Yu et al., 1995; Suppe et al., 1997; Lu et al., 1995; Hu et al., 1997; Lee et al., 1991, 1997; Angelier et al., 1997; Crespi et al., 1996). Detailed GPS surveys over the last decade (Yu et al., 1995) show a significant component of shortening between the offshore island Lanyu and the eastern flank of the Central Range. It is not known, however, how much shortening is taking place to the south of this region since GPS data are not available in the offshore region of the subduction zone where the structures are submerged.

The submarine accretionary prism consists of three distinct structural domains (Reed et al., 1992): a lower slope domain along the inner slope of the Manila Trench, an upper slope domain composed largely of the submarine Hengchun Ridge, and a backthrust domain along the rear of the submarine accretionary prism at the boundary between the Hengchun Ridge and the North Luzon Trough. These domains are found in both collision and subduction regions of the forearc. In the submarine portion of the collision, the backthrust domain (Fig. 2) exhibits several westdipping backthrusts and the North Luzon Trough, a forearc basin, is truncated by the juxtaposition of the rear of the prism with the island arc (Lieske et al., 1992; Lundberg et al., 1997). In the region of subduction, the forearc basin strata have been uplifted along the rear of the prism and dip eastward. Reed et al. (1992) inferred that uplift in this region resulted from the insertion of a tectonic wedge of prism material between a 2.5 -s-thick sequence of the forearc basin strata and the arc basement.

\section{Data acquisition and processing}

A multi-channel seismic (MCS) survey was conducted in the offshore regions surrounding southern Taiwan during the TAICRUST experiment with the R/ V Maurice Ewing from Columbia University in 1995 (Reed et al., 1996; Liu et al., 1997; Moore et al., 1997). Here we use MCS and gravity data collected along line EW9509.49 of the expedition and R/V Vema line V3618.49 (Nguyen et al., 1998) across the forearc basin in the region of subduction to the south.

\subsection{Reflection data}

The MCS data acquisition system included an 8420 cubic inches airgun array, composed of 20 airguns, and a 4.2-km-long 132-channel streamer. Shot interval was $50 \mathrm{~m}$ with recording to $16 \mathrm{~s}$. The data were processed at the University of Hawaii using the ProMAX processing package. Additional poststack processing and plotting were completed at San 

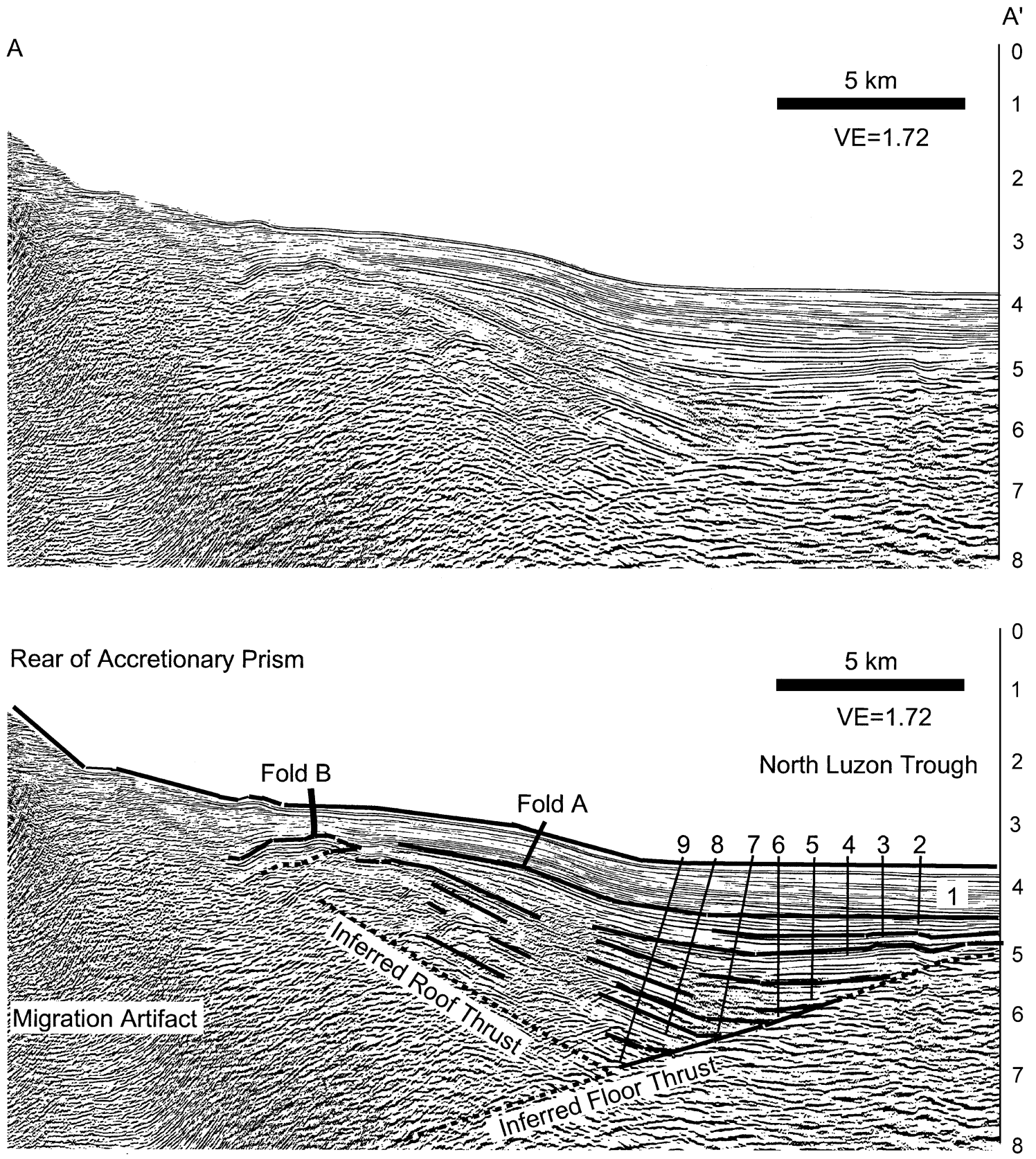

Fig. 2. Uninterpreted and interpreted portions of MCS line EW9509.49 that shows features within the west-flank of the forearc basin and the backthrust domain. For the forearc strata, we follow the seismic sequences by Hirtzel (1996). Note folding (Fold A) due to thickening and advancing of the tectonic wedge. Also see west dipping fault plane reflections within the tectonic wedge that propagate into the roof sequence. A fault propagation fold (Fold B) is above the tectonic wedge to the west. See Fig. 1 for the location of this cross section.

Jose State University using SIOSEIS. The overall processing sequence, described in Berndt and Moore (1999), included resampling at $4 \mathrm{~ms}$, geometry, true amplitude recovery, FK demultiple in both the shot and receiver domains, dip move out, velocity analysis, radon filter, 40 -fold weighted stack at $12.5 \mathrm{~m}$ 
CDP spacing, time variant frequency filter, FK or FD migration and automatic gain control. Different migration schemes have been tested and we found finite-difference (FD) migration gave better results for this section. The migration velocity was modified iteratively to reduce undermigration and overmigration artifacts at the same time. We then converted the profile to depth using the velocity models from interactive analysis (Fig. 3). The Vema line is processed in similar fashion and the details are described in Nguyen et al., (1998).

\subsection{Data analysis}

The North Luzon Trough is a forearc basin associated with the Manila Trench subduction zone in the region of line EW9509.49. Stratal reflections in the eastern portion of the basin are horizontal to subhorizontal and lap onto the western flank of the island arc (Fig. 2). These strata thicken to the west, towards the accretionary prism, and reach a total thickness of $2.5 \mathrm{~s}$ in two-way travel time (TWTT) or greater than 4 $\mathrm{km}$. Hirtzel (1996) divided the high amplitude, continuous reflections into nine seismic sequences, of which, the reflections in the upper three (1-3) seismic sequences diverge eastward and resemble growth strata that mark the onset of an episode of uplift due to tectonic wedging. These strata are ultimately incorporated into the rear of the accretionary prism by backthrusting in the region of collision in the formation of the Huatung Ridge (Reed et al., 1992). The forearc basin sediments were derived from a combination of sources, including the island arc, onland collision complex, and through submarine erosion of the prism (Lundberg, 1992; Lundberg et al., 1997; Hirtzel et al., 1994). Mass wasting along the rear of the accretionary prism also contributes debris to these deposits (Lundberg, 1992; Hirtzel et al., 1994).

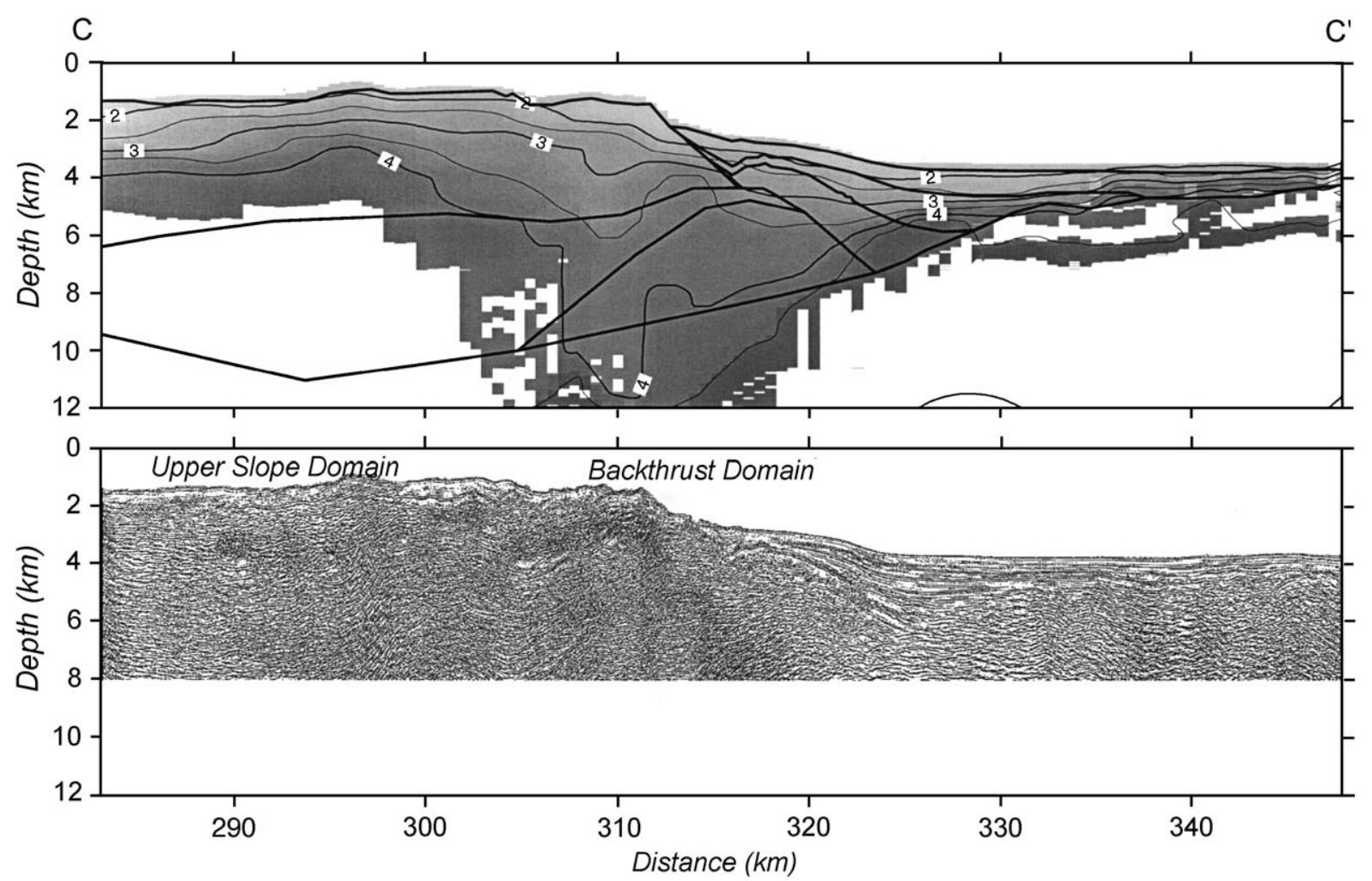

Fig. 3. The velocity section and uninterpreted section of the entire MCS line EW9509.49. The depth section in Fig. 2 is converted from time to depth using this velocity field, depicted in gray color contours in the upper panel. For location see Fig. 1. The thick lines in the upper panel show the geometry of the density model, as explained in the gravity modeling section of the text. 
The surface of the arc basement generally dips to the west, however, a 7-km-wide basement high with a relief of about $700 \mathrm{~m}$ (Fig. 2) is buried under the forearc strata in the vicinity of line EW9509.49. This feature may represent the western extent of the submerged portion of the island arc. To the west, the forearc basement dips smoothly to the west and may extend under the tectonic wedge, although the basement reflector is weak and not imaged beneath the prism.

On the west side of the North Luzon Trough, thick packages of reflections are tilted eastward along the rear of the prism. More than $1100 \mathrm{~m}$ of seafloor relief separates the apex of the tilted forearc basin reflections from the flat-lying sequences in the North Luzon Trough (Fig. 2). Minor conjugate thrust faulting, at a spacing of $2-3 \mathrm{~km}$, is common within the forearc basin strata. Reed et al. (1992) interpreted the uplift of these sequences as a result of backthrusting in the form of tectonic wedging.

Seismic sequences in the hanging wall of the roof thrust above the tectonic wedge (Fig. 2) show evidence of complex tectonic deformation, although a detailed analysis of this feature is beyond the scope of this study. A westward decrease in stratigraphic thickness causes an increase in bedding dip from $5^{\circ}$ to $30^{\circ}$ at greater depths. We follow the seismic sequence designation of Hirtzel (1996) to study the geometry of the youngest to the oldest strata, sequence 1 to sequence 9, respectively (Fig. 2). The thickness of sequence 1 increases from $500 \mathrm{~m}$ over the tectonic wedge to $800 \mathrm{~m}$ at the center of the forearc basin. Sequences 2 and 3 show erosional truncation, and the most dramatic changes in thickness from 300 to 900 $\mathrm{m}$, thereby forming divergent patterns of reflectors within seismic sequences. The thicknesses of sequences 4 through 9 vary from 1200 to $2700 \mathrm{~m}$, with the axis of an anticlinal fold in these strata shifted $4.5 \mathrm{~km}$ to the west of that observed in sequences 2 and 3 (cf. Fold A in Fig. 2). Thus the fold axis is partially eroded in sequences 3 and 4 , and somewhat disrupted by the west-dipping reflectors in sequences 5-9. West-dipping reflectors extend through the tectonic wedge and upwards across stratal reflections of the roof sequences. These features may be fault planes, which ultimately result in the incorporation of forearc-basin strata into the rear of the prism (Reed et al., 1999), although additional processing is required to rule out origins as diffractions, overmigration artifacts, or out- of-plane effects. The amount of offset across these protothrusts is less than the resolution of our data $(<40 \mathrm{~m})$, thus is interpreted as very small. The seismic character of sequences 1 through 3 is chaotic, resulting from debris flow deposits along the rear of the prism (Hirtzel, 1996). The floor thrust observed in line EW9509.49 can be traced at least $1.5 \mathrm{~km}$ further to the west than recognized in previous studies.

Another fold (Fold B in Fig. 2) is observed to the west of the crest of the main fold in forearc strata in the hanging wall of the roof thrust. The thickness of sequence 1 increases from 400 to $800 \mathrm{~m}$ westward in this fold. One east vergent fault-bend fold underlies sequence 1. Bedding has been offset by this fault. Sequences 2 and 3 have a relatively constant thickness of $300 \mathrm{~m}$. Several possible west-dipping fault plane reflections are interpreted under sequences 2 and 3. Sequences 4 through 9 are not recognized in this area. We have tested different migration schemes and different migration velocities to better image this portion of the profile and found that the FD method reduces high frequency noise, and that higher migration velocities will cause overmigration artifacts.

\subsection{Tectonic wedge}

We estimated the minimum shortening of forearc basin strata above the tectonic wedge by restoring the tilted units to an original, horizontal geometry. This calculation assumes no change in the length of bedding surfaces, little or no oblique movement, and horizontal deposition of sediments in the hanging wall of the roof thrust.

The forearc basin strata were flattened with a resulting shortening estimate of less than $2 \mathrm{~km}$ within the roof sequence. The amount of shortening related to the small-offset fault planes and folding in the roof sequences is less than $1 \mathrm{~km}$. Additional shortening to the west of these units, if it exists, cannot be measured due to chaotic character of the reflections, presumably related to deformation associated with sediment accretion along the Manila Trench during the early history of the prism.

Structures associated with shortening within the forearc strata can be divided into three packages (Fig. 4). The amount of shortening following the deposition of sequence 1 is approximately $0.5 \mathrm{~km}$ while the shortening following deposition of sequences 4 to 9 


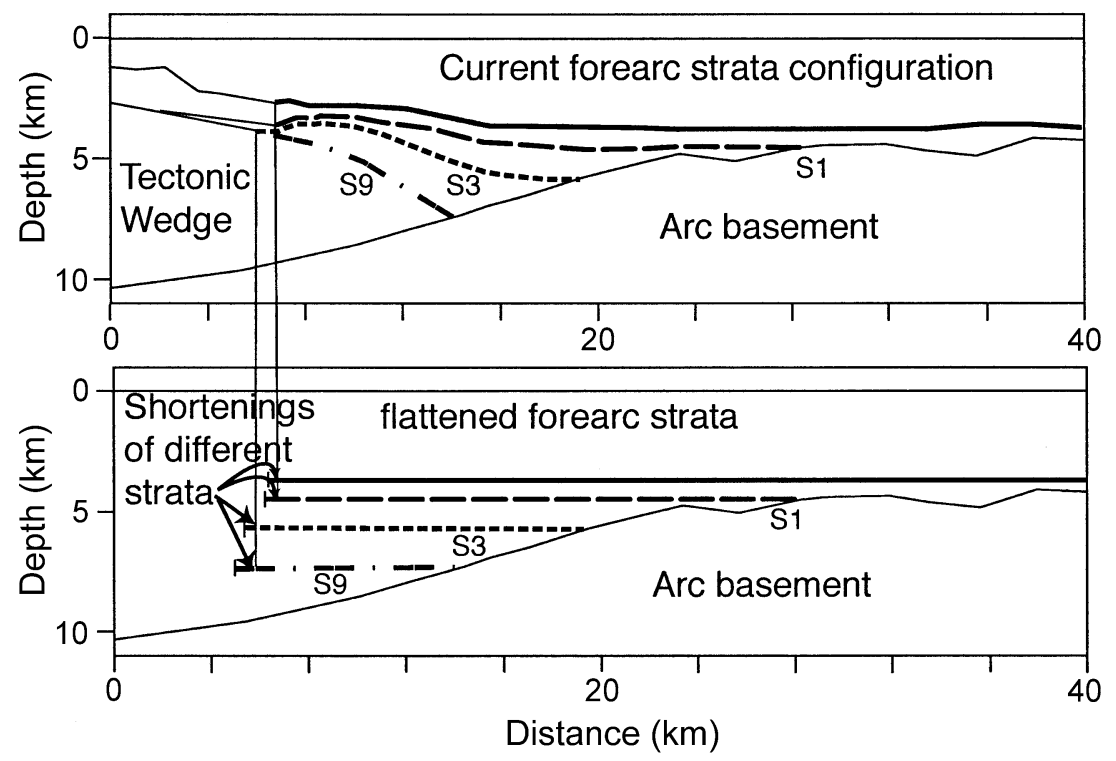

Fig. 4. Line balanced cross section of line EW9509.49. The forearc basin strata are divided into three major packages. Shortening within these packages shows less than $2 \mathrm{~km}$ of shortening. The wedge-shaped sequences 3 and 4 (the middle package) suggest non-uniform rates of either shortening or sedimentation. The lines used for balancing are the seafloor and the bases of sequences 1, 4, and 9. We do not consider bedding parallel shortening in this figure but will discuss it in the text.

ranges from 0.8 to $1.2 \mathrm{~km}$. The units with different amounts of shortening are separated by the wedgeshaped sequences 3 and 4, suggesting non-uniform rates of either shortening or sedimentation. The wedge movement to the east at depth might be larger than these shortening estimates from the balanced cross sections.

\subsection{Gravity data analysis}

Using the shallow crustal geometry derived from MCS data, we model the free-air gravity anomaly to constrain the geometry of the arc basement beneath the rear of the prism. We construct a transect of the entire forearc, from the arc to the trench, in the vicinity of the seismic interpretation of line EW9509.49 using the regional gravity data compilation of Hsu et al. (1998) sampled at a 1-km spacing. The extended transect will provide additional constraints for the long wavelength components of the anomaly in gravity modeling. These data were compared with the free-air gravity anomaly obtained along line EW9509.49 (Fig. 5). The gravity anomalies are similar in the two datasets, except that data on line
EW9509.49, which crosses only a portion of the forearc, includes an additional short wavelength component of the anomaly, not resolved in the regional compilation.

The initial model geometry of the forearc basin and rear of the prism (Fig. 6) was derived from the interpretation of MCS data. The densities of the forearc strata were inferred from the empirical velocity-density function by Godfrey et al. (1997) who compiled the $\mathrm{Vp}$ velocities and rock density data collected across the ancient forearc basement of the Great Valley and eastern slope of the Coastal Range of California. From the figure by Godfrey et al. we assigned 2.0, 2.1, 2.2, 2.3, 2.4, $2.5 \mathrm{~g} / \mathrm{cm}^{3}$ for $\mathrm{P}$ velocities of $1.9,2.2,2.5,2.8,3.3$, and $3.8 \mathrm{~km} / \mathrm{s}$, respectively. Igneous basement rocks and mantle rocks were assigned densities of 2.85 and $3.3 \mathrm{~g} / \mathrm{cm}^{3}$, respectively. The prism velocity is inferred from OBS refraction studies (Nakamura, personal communication, 1999; Nakamura et al., 1998). The geometry of the arc (Fig. 6) was modified from a crustal model based on the ocean-bottom seismograph (OBS) data by Chen and Nakamura (1998) collected $120 \mathrm{~km}$ to the north. Depth to the magnetic basement estimates 


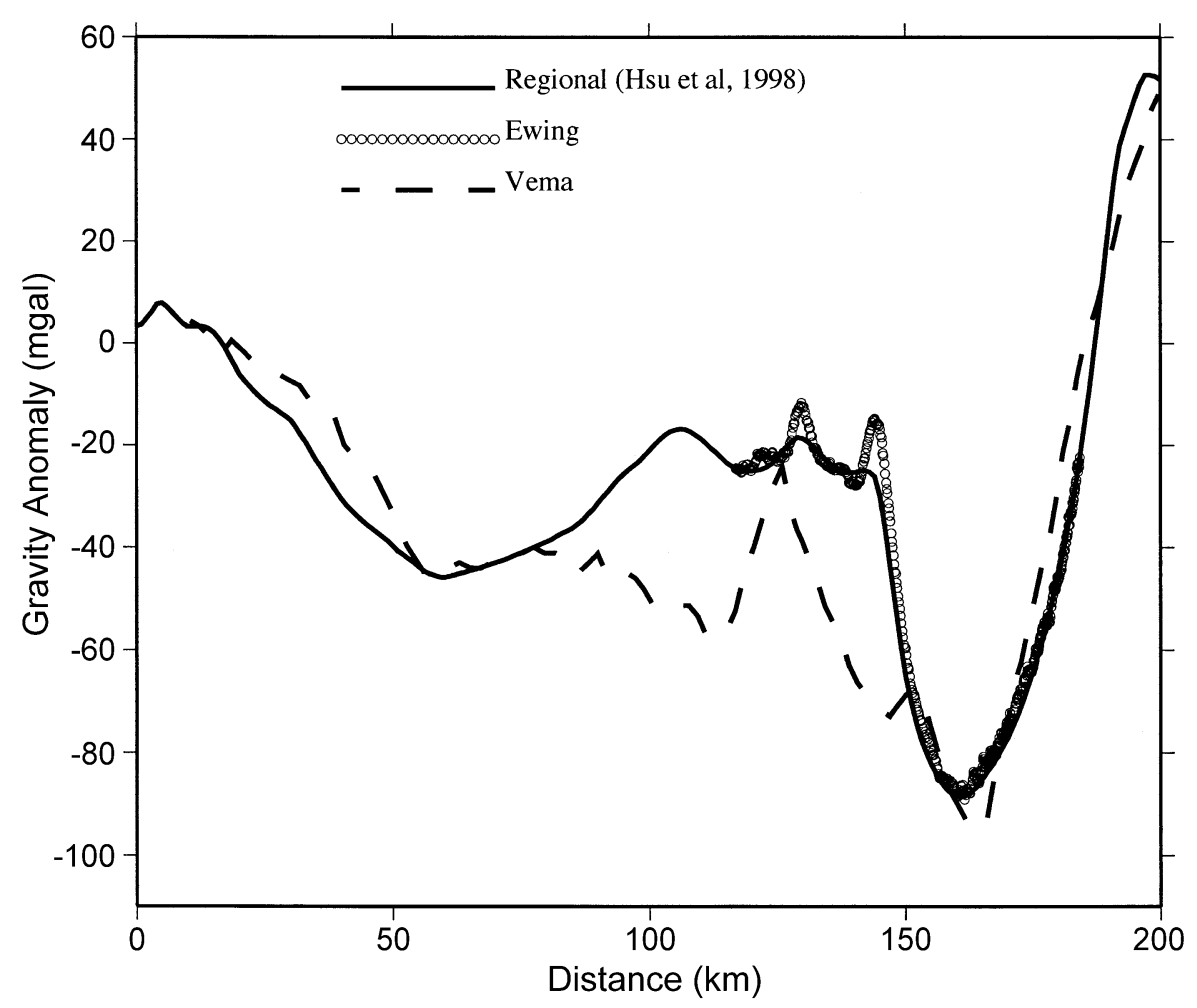

Fig. 5. Gravity data at the latitude $20.9^{\circ} \mathrm{N}$ from Hsu et al. (1998) is marked by solid line. It is very similar to the gravity data collected on board $\mathrm{R} / \mathrm{V}$ Ewing, marked by the circled line, which lacks the portion on the trench side. For comparison, we added the gravity data along the Vema line at latitude of $20.2^{\circ} \mathrm{N}$. We have shifted the anomaly horizontally and vertically for comparison. Note the low gravity anomaly over the backthrust domain in the V3618.49 line. To correlate the gravity anomaly with geologic features, see Figs. 6, 7, 8 and 9.

by Liu et al. (1992) was used to define the top of the subducting oceanic crust on the trenchward side of the accretionary prism. However, there is a gap of 40 $\mathrm{km}$ from the easternmost data point in the magnetic basement compilation to the westernmost identification of the arc basement beneath of the floor thrust on line EW9509.49. The dip of the subducting slab in this region is not well constrained by earthquake event locations and its sensitivity in influencing the calculated gravity anomaly will be tested in this study. At greater depths, the location of the slab is a bit better constrained by the depth phases of the deep earthquakes, as suggested by Bauststa et al. (2001). Thermal modeling of subduction zones by Anderson et al. (1978) was used as the first order approximation of the temperature field in the region. The densities of the lower crust and mantle rocks were then estimated from the phase equilbria relations presented in Hacker (1996). The thickness of the lithosphere was inferred as a wet, olivine-dominated, thermal boundary layer and estimated from the ages of the oceanic lithosphere in the Philippine Sea and South China Sea derived from magnetic data (Hilde and Lee, 1984; Taylor and Hayes, 1980) using Turcotte and Schubert (1982, p. 164, Eq. (4-126)):

$y_{\mathrm{L}}=2.32(\kappa t)^{1 / 2}$

where $y_{\mathrm{L}}$ is the thickness of the oceanic lithosphere, $\kappa$ is the thermal diffusivity, and $t$ is the age of the lithosphere.

For oceanic crust with an age of $30 \mathrm{Ma}$, the lithosphere thickness is about $72 \mathrm{~km}$. Like many other gravity studies, we choose not to introduce this complexity, below the Moho, into our gravity model because the great depth and the long wavelength of the structure should not produce the shorter-wavelength gravity anomaly over the tectonic wedge, which is the object of this study. 


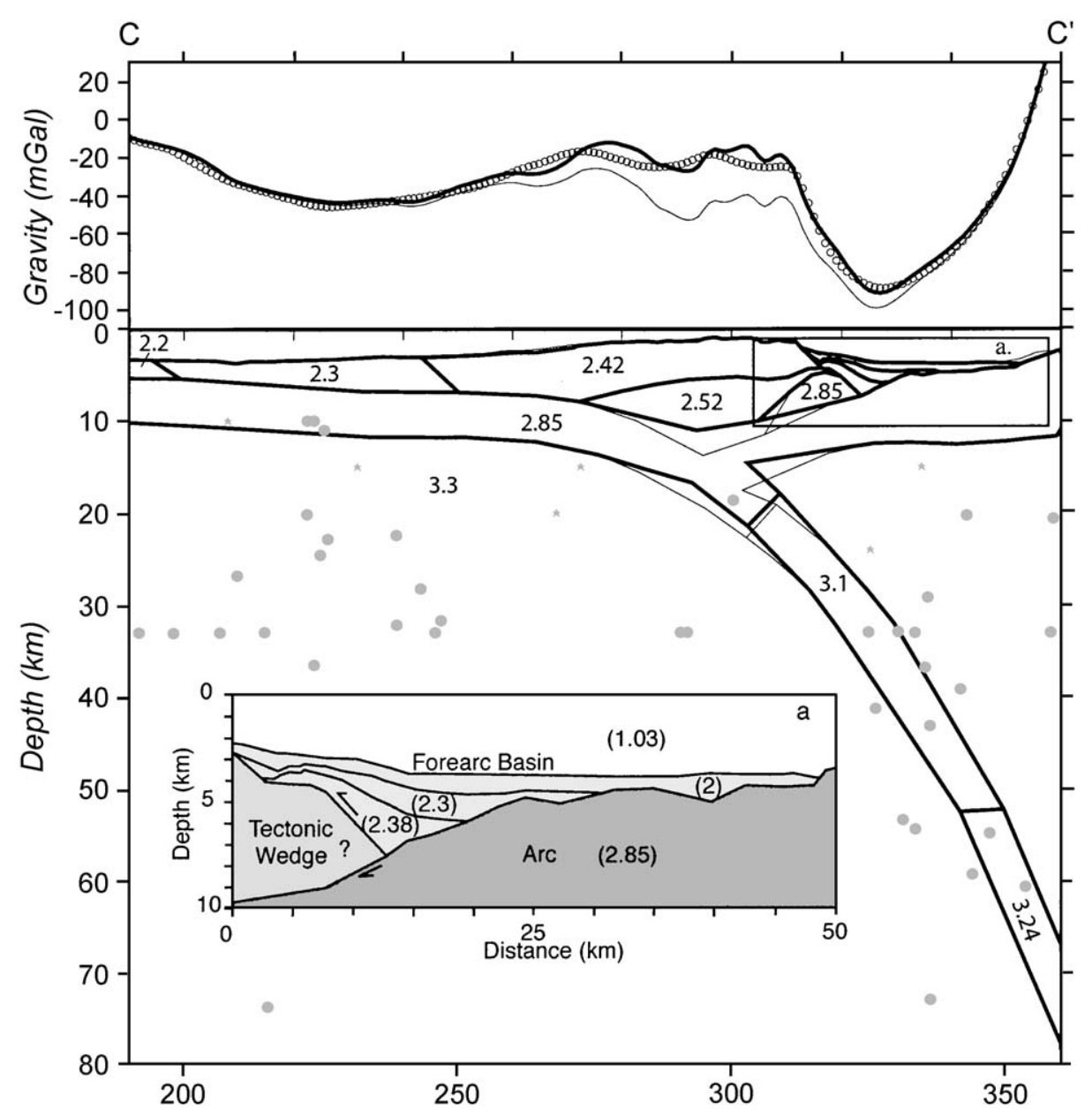

Fig. 6. Forearc geometry and density along the Ewing line for the gravity modeling. In the upper panel, the circles are the observed free-air gravity anomaly from Hsu et al. (1998). The thick line is the predicted gravity anomaly from the preferred model. The thin line is the result from a deeper slab model. In the lower panel, seismicity from the Bulletin of the International Seismological Centre Database (time span 1915-2000, marked as dots) and CNSS (time span 1960-1997, marked as stars) catalogs in the region within $35 \mathrm{~km}$ of the Ewing lines are plotted as circles for reference. The magnitudes of these earthquakes range from $\mathrm{Ms}=4.5$ to 6.5 . The thick lines show the geometry of our preferred model while the thin lines show a model from a sensitivity test using a steeper, deeper slab. The forearc basin in the rectangular outline is expanded to better show the density structures. The accretionary prism is modeled as being composed of three domains, a lower slope domain near the trench $\left(D=2.3 \mathrm{~g} / \mathrm{cm}^{3}\right)$, a upper slope domain making the offshore Hengchun Ridge $\left(D=2.42 \mathrm{~g} / \mathrm{cm}^{3}\right.$ for the top layer and $D=2.52 \mathrm{~g} / \mathrm{cm}^{3}$ for the bottom layer), and a backthrust domain along the rear of the prism that includes the tectonic wedge $\left(D=2.85 \mathrm{~g} / \mathrm{cm}^{3}\right)$. Forearc strata have densities ranging from 2 to $2.38 \mathrm{~g} / \mathrm{cm}^{3}$, based on the results from interactive velocity analysis.

\subsection{Gravity model in the vicinity of line EW9509.49}

Fig. 7 shows the gravity model the vicinity of line EW9509.49. The densities within the forearc basin vary from $2 \mathrm{~g} / \mathrm{cm}^{3}$ in shallow sediments to 2.38 at sub-bottom-depths of $4 \mathrm{~km}$. The bodies in our model with densities of $2.85 \mathrm{~g} / \mathrm{cm}^{3}$ are inferred to be igneous crust. The arc crust is modeled by a 5- $\mathrm{km}$-thick body with an upper surface dip of less than $15^{\circ}$ to the west. A high density body $\left(2.85 \mathrm{~g} / \mathrm{cm}^{3}\right)$ with an area of $40 \mathrm{~km}^{2}$ at depths between 4.5 and $10 \mathrm{~km}$ was embedded into the tectonic wedge. Because the geometry of this block is not well constrained, we can only approximate the area of the high density materials needed to model the freeair anomaly. 


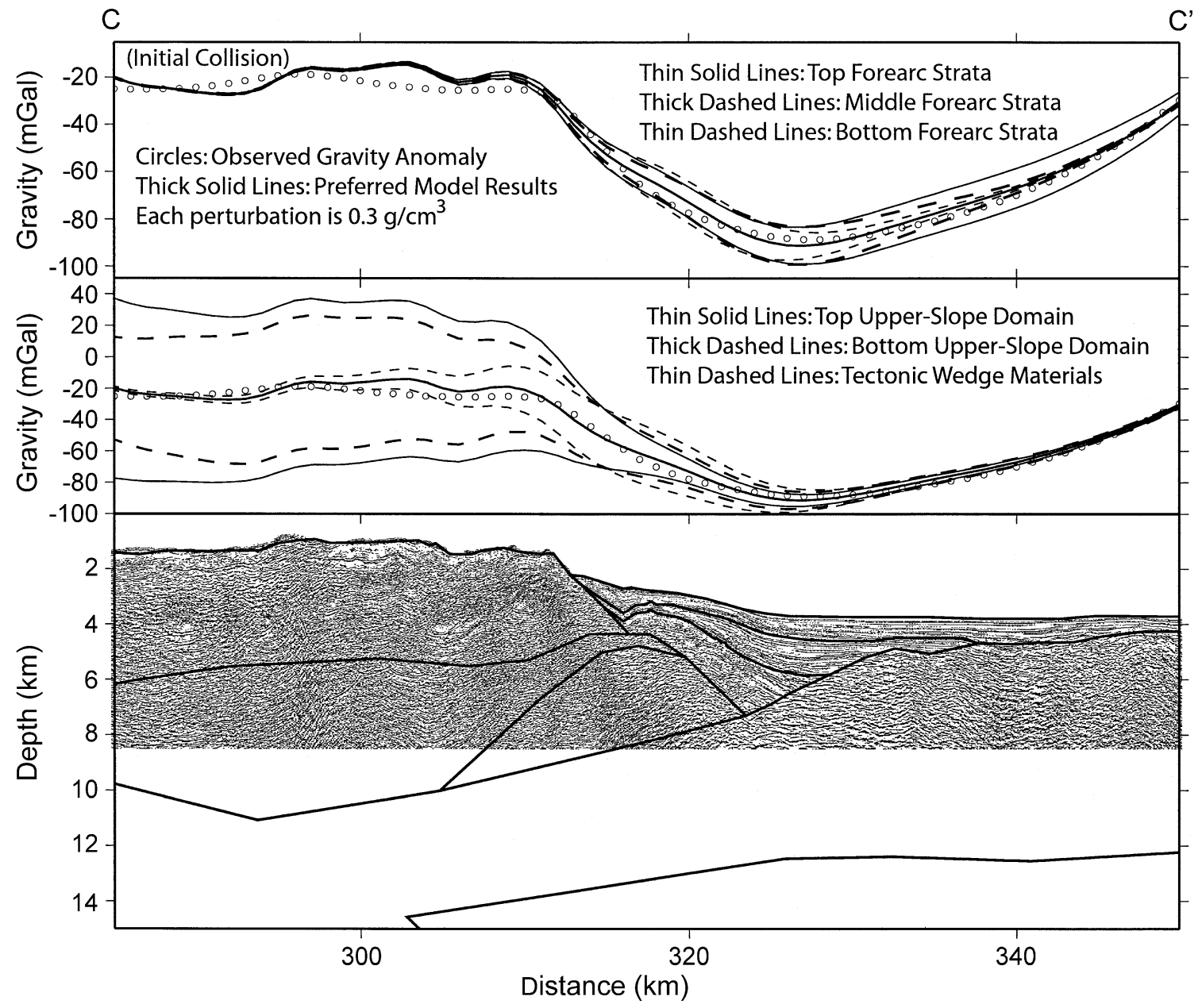

Fig. 7. Shallow density model overlaying reflection profile from line EW9509.49. The upper two panels show results from density sensitivity tests by perturbing $\pm 0.3 \mathrm{~g} / \mathrm{cm}^{3}$ of the top and bottom layers of the upper slope domain and the high-density block in the tectonic wedge, and the three layers in the forearc strata.

The sub-bottom depth of the Moho near the trench is about $7 \mathrm{~km}$, with a 6-km-thick igneous crust (Chen and Jaw, 1996). The dip of the subducting plate is about $3^{\circ}$ under a wedge-shaped body of deformed strata of the lower slope domain composed of sedimentary units with a density of $2.3 \mathrm{~g} / \mathrm{cm}^{3}$. The dip of the subducting plate increases to greater than $7^{\circ}$ below deformed units of the upper slope domain, which is modeled with a shallow block of $2.42 \mathrm{~g} /$ $\mathrm{cm}^{3}$ and a deeper block of $2.52 \mathrm{~g} / \mathrm{cm}^{3}$, inferred from a velocity model derived from a refraction studies 100 $\mathrm{km}$ north of this transect (Nakamura, unpublished data). The prism reaches a maximum thickness of
$10 \mathrm{~km}$. The dip of the subducting plate increases again to $50^{\circ}$ between a depth of 15 and $20 \mathrm{~km}$. Using the phase equilibria by Hacker (1996) and temperature modeling of Anderson et al. (1978), we estimated the subducting slab starts to metamorphose to blueschist facies at depths of $15 \mathrm{~km}$, then to eclogite facies at a depth of $50 \mathrm{~km}$. These features were included in the model, although they have little effect on the gravity anomaly at the wavelength we have modeled over the tectonic wedge.

To understand the robustness of the results, we perturbed block densities in the model to assess their influence on gravity anomaly over the tectonic wedge 
(Fig. 7). This exercise also serves to assess the contribution of each density block to the gravity anomaly. In particular, we were able to document the dominant wavelength of the gravity anomaly signals generated by each block for a range of density perturbations. Densities of six blocks, including three sedimentary layers in the forearc basin, the upper/ lower layers in upper slope domain, and high density block in the tectonic wedge, were perturbed by \pm 0.3 $\mathrm{g} / \mathrm{cm}^{3}$ with $\pm 0.1 \mathrm{~g} / \mathrm{cm}^{3}$ increments to predict the gravity anomaly variations.

We first examined the contribution of sediment density in the upper-slope domain to the gravity anomaly. The upper slope domain, across the Hengchun ridge, is divided into a top and a bottom layer to account for the vertical density gradient. Because we modeled the gravity anomaly across the whole subduction zone, we were able to use the simple and better-studied density structure on the trench side to further constrain the densities of the upper domain layers. Due to the shallow depth of this block, each $0.3 \mathrm{~g} / \mathrm{cm}^{3}$ of perturbation of the top upper domain layer will give $\sim 50 \mathrm{mgal}$, long-wavelength, gravity variation over the crest of the accretionary prism, which tapers off to $\sim 7 \mathrm{mgal}$ at the edge, just above the tectonic wedge. The bottom layer of the upper slope domain was created to represent the more deeply buried, higher density material. Because the thickness of this block varies little and because it is deeper, the perturbations in the modeled anomaly have very long wavelengths, especially over the tectonic wedge. Each $0.3 \mathrm{~g} / \mathrm{cm}^{3}$ change will cause a variation of less than $40 \mathrm{mgal}$, which tapers off to $\sim 4$ mgal at the edge, just above the tectonic wedge. For the high density materials in the tectonic wedge block, each change of $0.3 \mathrm{~g} / \mathrm{cm}^{3}$ will result in a less than 18 mgal variation over the tectonic wedge. Thus density variation within the tectonic prism exerts the strongest control on the modeled anomaly. Geometry of the forearc strata provides important constraints in our gravity analysis. However, densities of the strata is less influential: for each $0.3 \mathrm{~g} / \mathrm{cm}^{3}$ perturbation we found the calculated gravity anomaly only varies by 9, 9, and 5 mgal for the top, middle, and bottom layers, respectively.

By incorporating the structures near the trench into our models we were able to better constrain our overall density model, including in the vicinity of the tectonic wedge. The preferred model fits the longwavelength gravity signal well, but does not account for some local features. In particular, our preferred model over- and under-predicts the gravity anomaly by $4 \mathrm{mgal}$ over the portions of tectonic wedge, suggesting that there might be complex density variations at shallow depth in this region. The reflection profile in this region does not provide adequate control to add more geometric complexity to our model.

Sub-horizontal structures in the lower crust and mantle have little influence on the gravity anomaly at the rear of the prism. For example, an increase in the thickness of the arc crust to $9 \mathrm{~km}$ will result in an 8 mgal decrease in the free-air anomaly over the forearc basin. Changes in the thickness of the lithosphere have less influence on the free-air anomaly. Moreover, the short wavelength of the free-air anomaly over the rear of the prism requires a shallow crustal source and cannot be modeled to a first order with a deep source of the anomaly.

\subsection{Gravity model of Vema line V3618.49}

To compare deformation at different stages of subduction, we also modeled the crustal structure across the forearc region, approximately $70 \mathrm{~km}$ south of line EW9509.49. Nguyen et al. (1998) interpreted reprocessed MCS data collected along line V3618.49 by R/V Vema from the Lamont-Doherty Earth Observatory (LDEO). The geometry of the trench and dip of the subducting slab appear to be similar in the two regions (Kao et al., 2000). The depth section constructed along this line (Fig. 8), showing the geometry of the accretionary prism, was imported into the model, with a similar configuration of the subducting slab as used in the gravity model formulated in the vicinity of line EW9509.49.

The structure of the accretionary prism in this region is described in Nguyen et al. (1998). The prism is composed of three structural domains (Fig. 9), similar to that observed to the north. A sedimentary layer with a thickness from 200 to $600 \mathrm{~m}$ overlies a shallow east-dipping $\left(<10^{\circ}\right)$ oceanic crust under the lower slope domain. The width of the lower slope domain decreases by $30 \mathrm{~km}$ compared with that in the vicinity of the line EW9509.49. There is a sharp boundary from the 


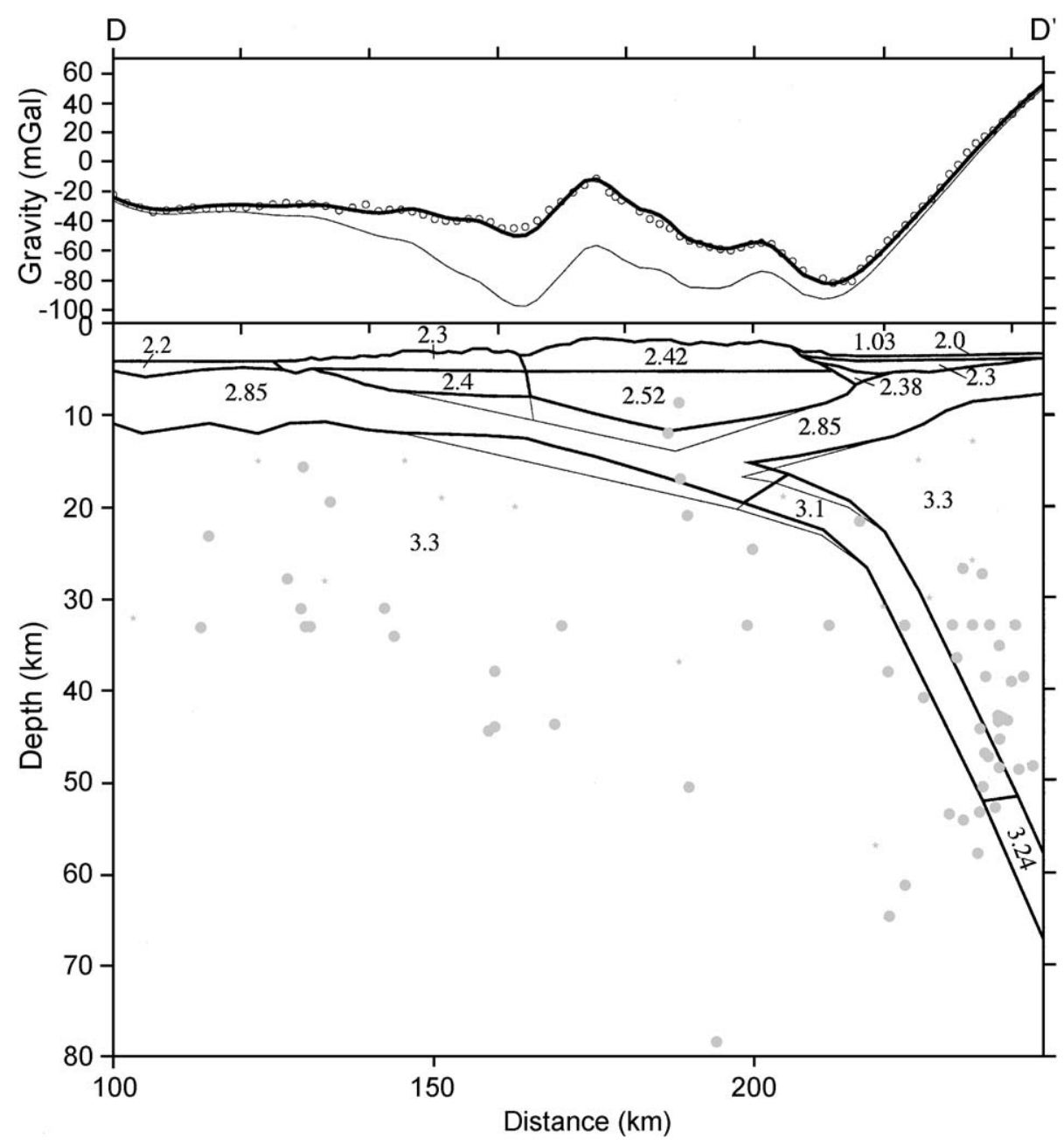

Fig. 8. The gravity modeling across subduction zone in the vicinity of line V3618.49. The geometry of the accretionary prism is based on the work by Nguyen et al. (1998). Note the tectonic wedge is mainly composed of low density materials in this model. Similar to Fig. 6, we have used thick lines to represent the model and the predicted gravity anomaly from our preferred model, while thin lines are for a steeper slab model plotted for reference. The range of the magnitudes of the earthquakes from (ISC and Harvard catalogs) is from Ms=4.3 to 6.5.

lower slope domain to the upper slope domain, marked by a $1.5-\mathrm{km}$-high scarp. The width of the upper slope domain is $25 \mathrm{~km}$ in this region. In the backthrust domain, a sedimentary tectonic wedge overlies a west dipping back stop, which is an extension of the top of the arc basement. The structure of the backthrust domain at first appears to be similar to that observed along line EW9509.49 and the sediment thicknesses in the two forearc regions are equivalent. The west-dipping fault plane reflections within the tectonic wedge and extending into the roof sequence are not present on line V3618.49. However, the data acquisition and processing schemes used in generating these two sections are significantly different.

The gravity anomaly can be modeled with a continuous west-dipping back stop extending under the tectonic wedge (Fig. 9) to the top of the subducting plate. Moreover, the entire prism, including the tectonic wedge, in the region of subduction can be modeled using density ranges of sedimentary rocks $\left(2.3-2.52 \mathrm{~g} / \mathrm{cm}^{3}\right)$. 


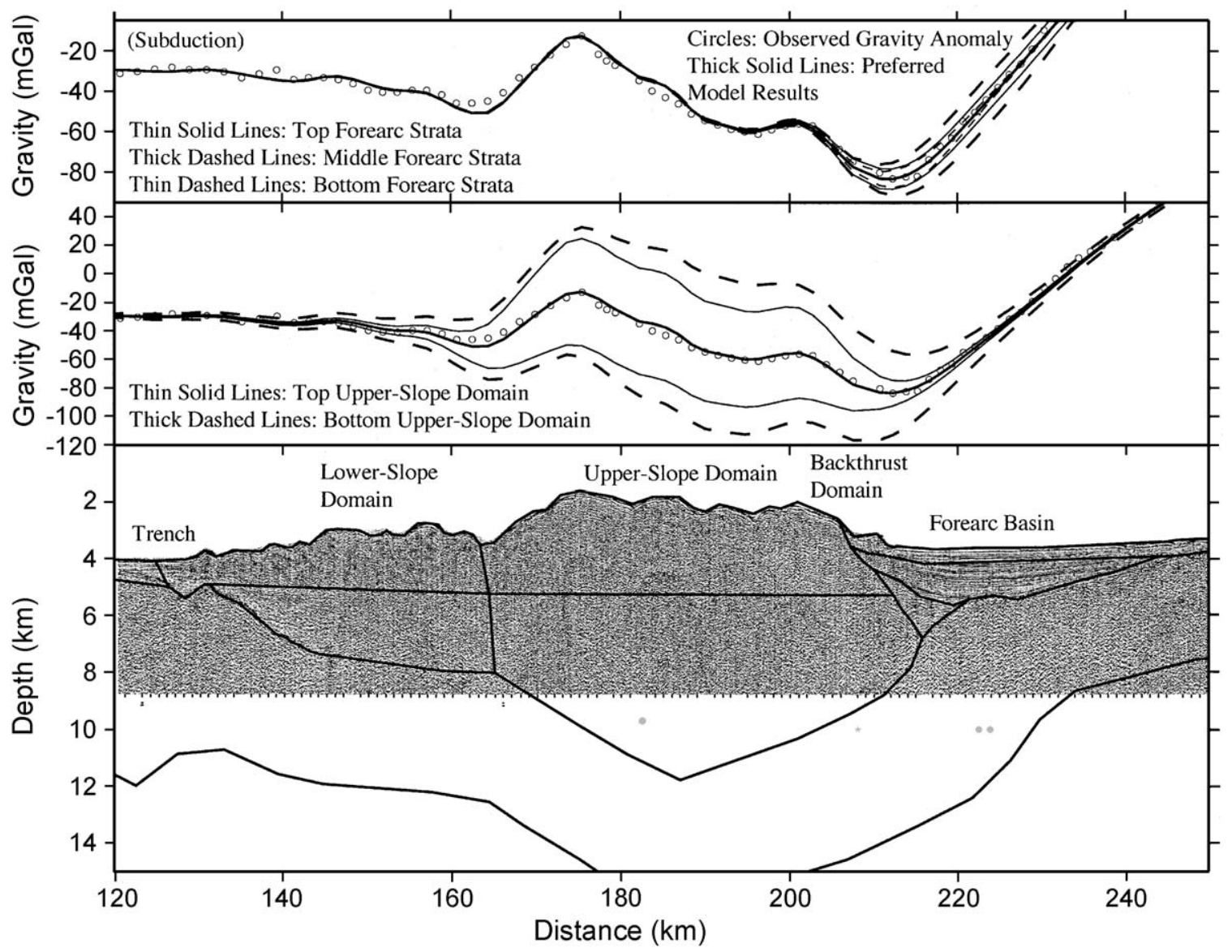

Fig. 9. Shallow density model overlaying reflection profile from Vema line V3618.49. In the upper panel, the circles are the observed gravity anomaly; the thick solid line is the preferred model; the thin solid lines, thick dashed lines, and thin dashed lines are the gravity anomalies result from perturbing $\pm 0.3 \mathrm{~g} / \mathrm{cm}^{3}$ of the top, middle, and bottom forearc strata, respectively. In the middle panel, the thin solid lines and the thick dashed lines are the gravity anomalies from the density sensitivity tests by perturbing $\pm 0.3 \mathrm{~g} / \mathrm{cm}^{3}$ of the top and bottom layers of the upper slope domain. The lower panel shows the geometry of the density model superimposed on reflection data. The small dots are the seismicity from ISC and Harvard catalogs.

Fig. 9 shows the sensitivity tests for modeling along line V3618.49. Because we are mainly interested in the density structure along the rear of the accretionary prism, we only tested the two-layer models of the upper slope domain, and the three layers of the forearc strata. Again we found the density perturbation of the forearc strata causes little effect: less than 6,8, and 5 mgal of gravity anomaly due to changes from $\pm 0.3 \mathrm{~g} / \mathrm{cm}^{3}$ of density perturbations for top, middle, and bottom layers, respectively. For the upper slope domain, the changes are $55 \mathrm{mgal}$ for $0.3 \mathrm{~g} / \mathrm{cm}^{3}$ increase in the top layer and $35 \mathrm{mgal}$ for lower layer.

\section{Discussion}

Shortening resulting in uplift and deformation of the roof sequence within the forearc basin in the vicinity of line EW9509.49 is less than $2 \mathrm{~km}$, based on the line balancing analysis. Factors that contribute errors in estimating the shortening include: errors in velocity field that was used to generate depth-corrected cross section, 3D complexity, non-horizontal deposition of forearc basin strata used in restoration, and layerparallel shortening in high porosity sediments.

The excellent signal to noise ratio and well-defined stratigraphy within the forearc strata make interactive 
velocity analysis relatively straightforward. By applying DMO to the sub-horizontal reflectors, we reduced the errors due to shallow dipping reflectors. Unfortunately, we do not have refraction data to cross check our velocity model used for depth conversion. However, even if we increase the velocity by $100 \%$, the increase in shortening will not exceed $3 \mathrm{~km}$, thus the errors from depth conversion should not be large.

We have examined the SeaMARC II and sixchannel MCS data collected by the R/V Moana Wave in the region (Reed et al., 1992). This dataset shows no dramatic change of stratigraphy across the tectonic wedge. As a result, strike-slip movement, at least in the forearc basin strata, does not pose severe problems for retrodeforming analysis in this particular cross section. Oblique slip may have occurred along faults further to the west or is higher on the rear slope of the prism.

The east dipping seafloor, above the roof sequence, suggests non-horizontal deposition of sediments within the roof sequence. However, the dips are relatively small and will result in less than $30 \%$ overestimate of shortening for a bathymetric slope of less than $20 \%$. The retrodeformed cross section uses a constant thickness for each sequence, which is different from the growth strata found in sequences 2 and 3. Thus this is not an "area-balanced" retrodeformation.

One uncertainty in line balancing in compressional regimes comes from layer-parallel shortening before the onset of folding, some of it associated with dewatering. Thus our estimates should be interpreted as the minimum shortening. We estimate that the deformed forearc strata have lengths of about 10 $\mathrm{km}$, translating into $4 \mathrm{~km}$ of shortening for a $40 \%$ parallel shortening before folding.

We also examined the forearc strata within line V3618.49 and found sequences 1 and 2 are less folded, indicating even less shortening compared with the region of line EW9509.49.

\subsection{Implications of the shortening}

We will assume that the variation in distance between the crest of the island arc to the apex of the accretionary prism is a first-order measure of crustal shortening within the forearc region related to the closure of the forearc basin in the region of collision. The distance between the crest of the accretionary prism to the arc is more than $50 \mathrm{~km}$ greater in the subduction zone region at a latitude of $20.2^{\circ} \mathrm{N}$ than in the collision zone at $22.7^{\circ} \mathrm{N}$. Several west-dipping faults were imaged in the collision region, showing increasing shortening along the rear of the prism from south to the north (Reed et al., 1992; Lundberg et al., 1997; Malavieille et al., in press). Tang and Chemenda (2000) proposed that forearc basin basement starts to subduct underneath the collided Luzon Arc in the collision zone. Assuming a constant shortening of $40 \mathrm{~mm} /$ year, similar to that observed in recent GPS studies between the islands southeast of Taiwan and the east side of the Central Range (Yu et al., 1995), we estimated that the decreased width is equivalent to $1-$ 1.5 my of shortening. Using the time-space equivalence graph (Fig. 1b) we converted the time duration into distance along the convergent boundary, which is $100-150 \mathrm{~km}$ south of the $22.7^{\circ} \mathrm{N}$. This analysis suggests that the southernmost point of significant shortening is located between $21^{\circ}$ and $21.5^{\circ} \mathrm{N}$, which corresponds to the location where the forearc basin starts to collapse as in the modern setting. If the shortening rates between the accretionary prism and the island arc are less than $40 \mathrm{~mm} /$ year, the initial shortening point would be further south.

Even though the observed difference in shortening seems to fit the time-space equivalence concept well, we cannot exclude other alternative mechanisms that may account for larger shortening on land compared with the offshore region. For example, the incoming passive margin in the collision zone may result in shortening in other regions of the forearc, such as the active backthrusting west of the tectonic wedge, which may accommodate part of the missing shortening in the subduction region. The intensive deformation in that region makes it very difficult to identify any offsets due to potential backthrusts. However, the bathymetry of the eastern slope of the prism shows little variation from the subduction region to the point of incipient collision, suggesting similar shortening rates in the back thrust domain, west of the tectonic wedge, prior to collision. We have mapped fault-plane reflectors that propagate into the roof sequence near the point of incipient collision. The small offsets of the strata in the roof sequence across these faults suggest that the deformation is relatively young and the amount of shortening is small. On the other hand, the shortening within the tectonic wedge must be 
larger than that of the roof sequence, in order to generate the 4-km uplift. Unfortunately, we do not have good geometry and kinematics data within the tectonic wedge to study more detailed shortening in that region.

\subsection{Implications of free-air gravity modeling in the vicinity of the tectonic wedge}

It is not the purpose of this study to constrain all the elements of the subduction zone. However, we hope to develop a framework, and from sensitivity tests, identify the major structures that contribute to the free-air gravity anomaly observed over the rear of prism in the regions of subduction and initial collision.

The results of our gravity modeling indicate that the prism in the region of subduction along line V3618.49 is mainly sedimentary. Once the mantle and the subducting slab are added to the model, derived from the MCS data, the gravity anomaly required either a very thick forearc crust (greater than $50 \mathrm{~km}$ ), or as a more reasonable alternative, lowdensity materials composing the rear of the prism and the tectonic wedge.

The free-air anomaly along line EW9509.49 shows a 70-mgal increase from forearc basin to backthrust domain compared a 30-mgal increase over the same region along V3618.49 in the area of subduction. The differences in bathymetry along these two transects can contribute 20 mgal of the gravity anomaly deficiency. The magnitude of the gravity anomaly decays as the inverse of the square of distance, thus shallow bathymetry, being closer to the sea surface where gravity data was observed, has big influence on the predicted anomaly. In our study, the bathymetry is well constrained by swath-mapping and MCS data. The remaining anomaly deficiency must be related to different density structures at depth. Sensitivity tests show that either the entire backthrust domain must be assigned a density of $2.6 \mathrm{~g} / \mathrm{cm}^{3}$ or that a high density (2.85) body composes a significant portion of the material under the roof thrust.

We prefer the high density body interpretation over the uniform $2.6 \mathrm{~g} / \mathrm{cm}^{3}$ tectonic wedge interpretation because density of $2.6 \mathrm{~g} / \mathrm{cm}^{3}$ is approaching the upper bound for siliclastic sediments (Turcotte and Schubert, 1982), yet we have identified several bottom-simulating reflectors (BSRs) along the rear of the accretion- ary prism in this region (Chi et al., 1998), which suggests that this region is mostly sedimentary, at least to a subbottom depth of several hundred meters. Also, the high density body in the tectonic wedge modeled in line EW9509.49 may extend northward along rear of prism to a region that shows tomographic evidence for a high velocity body (Cheng et al., 1998).

Several mechanisms may account for the incorporation of high density materials into the tectonic wedge along line EW9509.49. High-density basement rocks could be incorporated into the tectonic wedge from the basement beneath the forearc basin, similar to a mechanism proposed by Godfrey et al. (1997) to explain the tectonic wedging in California. Because the shortening of the roof sequence along line EW9509.49 is about $1 \mathrm{~km}$ greater than that of line V3618.49, part of the uplifted basement could be due to the differential shortening of the lower crust under and within the tectonic wedge. Based on field studies of ophiolitic mélange on land to the north, Chang et al. (2000) proposed that the outcropped oceanic crust most likely arose from lower forearc sequences. Basement-involved tectonic wedges have been proposed in other regions around the world, including Canada, USA, and Australia (Price, 1986; Godfrey et al., 1997; Mitra and Mount, 1998; Flottmann and Hand, 1999).

These small $\left(<40 \mathrm{~km}^{2}\right.$ in cross section view) high density bodies could also be interpreted as underplated materials derived from the downgoing lithosphere. Based on paleogeographic and geochronologic data, the melange and ophiolitic materials found in an analogous position in the collision zone onland have been interpreted as part of the South China Sea lithosphere (e.g. Liu et al., 1977; Suppe, 1988). If this is the case, our gravity models do not capture the evolution and transport of these bodies from the subduction region to the initial collision region.

The gravity study also shows that the prism can be modeled with a double vergent orogen type of deformation, especially in the region of subduction. The trenchward dipping arc basement acts as a backstop that can cause backthrusting and backfolding where accompanied by shortening. The gravity anomaly in the latitude of $20.2^{\circ} \mathrm{N}$ suggests no dramatic uplift or deformation of basement. In contrast, gravity modeling results suggest that the basement materials have been uplifted at the latitude of $20.9^{\circ} \mathrm{N}$. We cannot rule 
out the possibility of an arcward dipping fault, as proposed in the collision region farther to the north, based on the gravity modeling alone. The gravity anomaly can be modeled with a trenchward dipping back stop, and uplifted basement rocks in the region of incipient collision, which is consistent with the model of a double vergent orogen, at least in this region of the initial collision.

\section{Summary}

The structure of the boundary between the accretionary prism and forearc basin in the subduction zone, offshore southern Taiwan, resembles that associated with tectonic wedges found elsewhere in the world. Multi-channel seismic data provide new constraints on the structural geometry in this region. The tectonic wedge is bounded by a $30^{\circ}$ east-dipping roof thrust, and a $15^{\circ}$ west-dipping floor thrust. The tip of the tectonic wedge is buried under $4 \mathrm{~km}$ of forearc strata. The strata of the roof sequence are tilted eastward and uplifted more than $1 \mathrm{~km}$ due to tectonic wedging. We performed line retrodeformation to estimate the minimum shortening within the roof sequence above the tectonic wedge, which is less than $2 \mathrm{~km}$ over last few million years. Bedding parallel shortening can add another $4 \mathrm{~km}$ of shortening. This shortening is very small compared with the current shortening in the collision measured by GPS, which predicts more than $40 \mathrm{~km}$ of shortening over 1 million years. The difference in shortening can be explained by a shift in the location of crustal shortening from the trench in the subduction region to other regions of forearc in the collision zone, including the region between the Hengchun Peninsula and the island of Lanyu (Yu et al., 2001).

Gravity modeling suggests that the tectonic wedge and the rear of the accretionary prism are mainly composed of sediments in the region of subduction at the latitude of $20.2^{\circ} \mathrm{N}$. However, basement rocks may exist along the rear of the accretionary prism in the collision region beginning at $20.9^{\circ} \mathrm{N}$ and may extend northward to outcrops on land. These results imply that a trenchward dipping arc basement acts as a backstop to a double vergent orogen or that a fundamental change in deformation style must occur between the point of incipient collision in the offshore and the Central Ranges in order to accommodate an east-dipping fault on land.

\section{Acknowledgements}

We thank Dr. G.K. Westbrook and Dr. K.D. McIntosh for their careful reviews and constructive criticism. We also want to thank the captain and the crew members of the R/V Maurice Ewing of the Columbia University. Especially, line EW9509.49 used in this study was surveyed after we encountered five typhoons in the 1-month cruise. WCC thanks Matthew d'Alessio for helpful discussion. Most of the figures were generated using GMT and SIOSEIS. Dr. Paul Henkart is thanked for his help on SIOSEIS. This research is partially funded by NSF Grant OCE9416583 to Dr. Donald Reed at San Jose State University. This is Contribution Number 03-05 of the UC Berkeley Seismological Laboratory.

\section{References}

Anderson, R.N., DeLong, S., Schwarz, W.M., 1978. Thermal model for subduction with dehydration in the downgoing slab. Journal of Geology 86 (6), 731-739.

Angelier, J., Chu, H.-T., Lee, J.-C., 1997. Shear concentration in a collision zone; kinematics of the Chihshang Fault as revealed by outcrop-scale quantification of active faulting, Longitudinal Valley, eastern Taiwan. Tectonophysics 274, 117-143.

Bauststa, B.C., Bautista, M.L.P., Oike, K., Wu, F.T., Punongbayan, R.S., 2001. A new insight on the geometry of subducting slabs in northern Luzon, Philippines. Tectonophysics 339, 279-310.

Berndt, C., Moore, G.F., 1999. Dependence of multiple-attenuation techniques on the geologic setting: a case study from offshore Taiwan. The Leading Edge 18 (1), 74-80.

Bowin, C., Lu, R.-S., Lee, C.-S., Schouten, H., 1978. Plate convergence and accretion in Taiwan-Luzon region. American Association of Petroleum Geologists Bulletin 62 (9), 1645-1672.

Byrne, T., Crepsi, J., 1997a. Introduction to the Geology of Taiwan: Field Guidebook for the International Conference and SinoAmerican Symposium on Tectonic of East Asia, pp. 5-15.

Byrne, T., Crepsi, J., 1997b. Kinematics of the Taiwan Arc-continent collision and implications for orogenic processes [abs.]. International Conference and Sino-American Symposium on Tectonic of East Asia, p. 38.

Chang, C.-P., Angelier, J., Huang, C.-Y., 2000. Origin and evolution of a mélange: the active plate boundary and suture zone of the Longitudinal Valley, Taiwan. Tectonophysics 325, 43-62.

Chemenda, A.I., Yang, R.-K., Stephan, J.-F., Konstantinovskaya, 
E.A., Ivanov, G.M., 2001. New results from physical modelling of arc-continent collision in Taiwan: evolutionary model. Tectonophysics 333, 159-178.

Chen, A.T., Jaw, Y.-S., 1996. Velocity structure near northern Manila Trench; an OBS refraction study. Terrestrial, Atmospheric and Oceanic Sciences 7 (3), 277-297.

Chen, A.T., Nakamura, Y., 1998. Velocity structure beneath the eastern offshore region of Southern Taiwan based on OBS data. Terrestrial, Atmospheric and Oceanic Sciences (TAO) 9 (3), 409-424.

Cheng, W.-B., Wang, C., Shyu, C.-T., Shin, T.-C., 1998. A threedimensional $\mathrm{Vp}$ model of the Southeastern Taiwan area and its tectonic implications. Terrestrial, Atmospheric and Oceanic Sciences (TAO) 9 (3), 425-452.

Chi, W.-C., Reed, D., Liu, C.S., Lundberg, N., 1998. Distribution of the bottom-simulating reflector in the offshore Taiwan collision zone. Terrestrial, Atmospheric and Oceanic Sciences (TAO) 9 (4), 779-794.

Crespi, J.M., Chan, Y.-C., Swaim, M.S., 1996. Synorogenic extension and exhumation of the Taiwan hinterland. Geology (Boulder) 24 (3), 247-250.

Fisher, D., Willett, S.D., 1998. Finite strain, kinematics and wedge dynamics of Taiwan [abs.]. EOS (Transactions, American Geophysical Union) 79, 918.

Flottmann, T., Hand, M., 1999. Folded basement-cored tectonic wedges along the northern edge of the Amadeus Basin, Central Australia: evolution of orogenic shortening. Journal of Structural Geology 21, 399-412.

Godfrey, N.J., Beaudoin, B.C., Klemperer, S.L., Levander, A., Luetgert, J., Meltzer, A., Mooney, W., Trehu, A., 1997. Ophiolitic basement to the Great Valley forearc basin, California, from seismic and gravity data; implications for crustal growth at the North American continental margin. Geological Society of America Bulletin 109 (12), 1536-1562.

Hacker, B.R., 1996. Eclogite formation and the rheology, buoyancy, seismicity, and $\mathrm{H}_{2} \mathrm{O}$ content of oceanic crust. Geophysical Monograph 96, 337-346.

Hilde, T.W.C., Lee, C., 1984. Origin and evolution of the West Philippine Basin; a new interpretation. Tectonophysics 102, $85-104$

Hirtzel, J.O., 1996. Evolution of a forearc basin in arc-continent collision, offshore Taiwan. Master's thesis, San Jose State University. $41 \mathrm{pp}$.

Hirtzel, J., Reed, D.L., Lundberg, N., Liu, C.S., 1994. Seismic stratigraphic evolution of a forearc basin involved in arc-continent collision, offshore Taiwan [abs.]. EOS (Transactions, American Geophysical Union) 75 (44), 672.

Hsu, S.-K., Liu, C.-S., Shyu, S.-T., Liu, S.-Y., Sibuet, J.-C., Lallemand, S., Wang, C., Reed, D., 1998. New gravity and magnetic anomaly maps in the Taiwan-Luzon region and their preliminary interpretation. Terrestrial, Atmospheric and Oceanic Sciences (TAO) 9 (3), 509-532.

Hu, J.-C., Angelier, J., Yu, S.-B., 1997. An interpretation of the active deformation of southern Taiwan based on numerical simulation and GPS studies. Tectonophysics 274 (1-3), 145-169.

Jachens, R.C., Griscom, A., Roberts, C.W., 1995. Regional extent of Great Valley basement west of the Great Valley, California: implications for extensive tectonic wedging in the California Coast Ranges. Journal of Geophysical Research, B, Solid Earth and Planets 100 (7), 12769-12790.

Jadoon, I.A.K., Frisch, W., 1997. Hinterland-vergent tectonic wedge below the Riwat Thrust, Himalayan foreland, Pakistan; implications for hydrocarbon exploration. American Association of Petroleum Geologists Bulletin 81 (3), 438-448.

Kao, H., Huang, G.-C., Liu, C.-S., 2000. Transition from oblique subduction to collision in the northern Luzon arc-Taiwan region: constraints from bathymetry and seismic observations. Journal of Geophysical Research 105, 3059-3080.

Lawton, D.C., Sukaramongkol, C., Spratt, D.A., 1996. Seismic characterization of a compound tectonic wedge beneath the rocky mountain foreland basin, Alberta. Bulletin of Canadian Petroleum Geology 44 (2), 258-268.

Lee, T.-Q., Kissel, C., Barrier, E., Laj, C., Chi, W.-R., 1991. Paleomagnetic evidence for a diachronic clockwise rotation of the coastal range, eastern Taiwan. Earth and Planetary Science Letters $104(2-4), 245-257$.

Lee, J.-C., Angelier, J., Chu, H.-T., 1997. Polyphase history and kinematics of a complex major fault zone in the northern Taiwan mountain belt; the Lishan Fault. Tectonophysics 274, 97-115.

Lieske Jr., J., Lundberg, N., Reed, D.L., 1992. Backthrusting in the submarine Taiwan orogeny; SeaMARC II and seismic reflection data. Acta Geologica Taiwanica 30, 141-144.

Lin, C.-H., Yeh, Y.-H., Yen, H.-Y., Chen, K.-C., Huang, B.-S., Roecker, S., Chiu, W., 1998. Three-dimensional elastic wave velocity structure of the Hualien region of Taiwan; evidence of active crustal exhumation. Tectonics 17 (1), 89-103.

Liu, J.G., Lan, C.-Y., Suppe, J., Ernst, W.G., 1977. The east Taiwan Ophiolite: its occurrence, petrology, metamorphism and tectonic setting. Mining Research and Service Organization Special Report No. 1. Taipei, Taiwan, ROC. 187 pp.

Liu, C.-S., Liu, S.Y., Kao, B.-Y., Lundberg, N., Reed, D.L., 1992. Characteristics of the gravity and magnetic anomalies off southern Taiwan. Acta Geologica Taiwanica 30, 123-130.

Liu, C.-S., Lallemand, S.E., Lin, S.-J., Schnurle, P., Reed, D.L., 1997. Forearc structures of the Ryukyu subduction-Taiwan collision zone from seismic reflection studies east of Taiwan [abs.]. EOS (Transactions, American Geophysical Union) 78, 718.

Lu, C.-Y., Angelier, J., Chu, H.-T., Lee, J.-C., 1995. Contractional, transcurrent, rotational and extensional tectonics; examples from northern Taiwan. Tectonophysics 246 (1-3), 129-146.

Lundberg, N., 1992. Structural controls on orogenic sedimentation, submarine Taiwan collision. Acta Geologica Taiwanica 30, $131-140$.

Lundberg, N., Reed, D.L., Liu, C.-S., Lieske Jr., J., 1997. Forearcbasin closure and arc accretion in the submarine suture zone south of Taiwan. Tectonophysics 274, 5-23.

Malavieille, J., Lallemand, S.E., Dominguez, S., Deschamps, A., Lu, C.-Y., Liu, C.-S., Schnurle, P., and the ACT Scientific Crew, in press. Geology of the Arc-Continent Collision in Taiwan: Marine Observations and Geodynamic Model, GSA.

Mitra, S., Mount, V.S., 1998. Foreland basement-involved structures. American Association of Petroleum Geologists 82 (1), $70-109$.

Moore, G.F., Taylor, B., Zhao, Z., Chi, W.-C., Reed, D.L., Lundberg, 
N., Liu, C.S., 1997. Structure of the China margin southwest of Taiwan form new multichannel seismic reflection data [abs.]. EOS (Transactions, American Geophysical Union) 78, F658.

Nakamura, Y., McIntosh, K., Chen, A.T., 1998. Preliminary results of a large offset seismic survey west of Hengchun Peninsula, southern Taiwan. Terrestrial, Atmospheric and Oceanic Sciences (TAO) 9 (3), 395-408.

Nguyen, T.A., Reed, D.L., Chi, W.-C., 1998. New insights into forearc processes within the subduction-related portion of the offshore Taiwan accretionary prism, [abs.]. EOS (Transactions, American Geophysical Union) 79 (45), 887.

Price, R., 1986. The southeastern Canadian Cordillera: thrust faulting, tectonic wedging and delamination of the lithosphere. Journal of Structural Geology 8 (3-4), 239-254.

Reed, D.L., Silver, E.A., 1995. Sediment dispersal and accretionary growth of the North Panama deformed belt: special paper. Geological Society of America 295, 213-223.

Reed, D.L., Lundberg, N., Liu, C.-S., Kuo, B.-Y., 1992. Structural relations along the margins of the offshore Taiwan accretionary wedge; implication for accretion and crustal kinematics. Acta Geologica Taiwanica 30, 105-122.

Reed, D.L., Chi, W.-C., Moore, G.F., Berndt, C., Zhao, Z., Lundberg, N., Nakamura, Y., McIntosh, K., Liu, C.S., 1996. TAICRUST; imaging forearc deformation during arc accretion [abs.]. EOS (Transactions, American Geophysical Union) X, 719.

Reed, D.L., Lundberg, N., Chi, W.-C., Silver, E.A., Liu, C.-S., Moore, G.F., 1999. Modern arc-continent collisions of the pacific rim: implications for the development and demise of forearc basins. Geological Society of America, Annual Meeting, Berkeley, CA, USA, A-87.

Silver, E.A., Reed, D., 1988. Backthrusting in accretionary wedges. Journal of Geophysical Research 93 (4), 3116-3126.

Silver, E.A., Abbott, L., Kirchoff-Stein, K.S., Reed, D., Bernstein, B., 1990. Collision propagation in Papua New Guinea and Solomon Sea. Fifth Circum-Pacific Energy and Mineral Resources Conference, Honolulu, HI, USA, 1001.

Suppe, J., 1984. Kinematics of arc-continent collision, flipping of subduction, and back-arc spreading near Taiwan. Memoir of the Geological Society of China 6, 21-33.

Suppe, J., 1988. Tectonics of arc-continent collision on both sides of the South China Sea: Taiwan and Mindoro. Acta Geologica Taiwanica 26, 1-18.

Suppe, J., Sabat, F., Munoz, J.A., Poblet, J., Roca, E., Verges, J.,
1997. Bed-by-bed fold growth by kink-band migration; Sant Llorenc de Morunys, eastern Pyrenees. Journal of Structural Geology 19, 443-461.

Tang, J.-C., Chemenda, A.I., 2000. Numerical modeling of arccontinent collision. Application to Taiwan 325, 23-42.

Taylor, B., Hayes, D.E., 1980. The tectonic evolution of the South China Basin. Geophysical Monograph 23, 89-104.

Teng, L.S., 1990. Tectonic evolution of late Cenozoic arc-continent collision in Taiwan. American Association of Petroleum Bulletin 74 (6), 1004-1005.

Torrini Jr., R., Speed, R.C., 1989. Tectonic wedging in the forearc basin-accretionary prism transition, Lesser Antilles forearc. Journal of Geophysical Research, B, Solid Earth and Planets 94 (8), 10549-10584.

Turcotte, D.L., Schubert, G., 1982. Geodynamics: Applications of Continuum Physics to Geological Problems. Wiley, New York, NY, USA. 450 pp.

Unruh, J.R., Loewen, B.A., Moores, E.M., 1995. Progressive arcward contraction of a Mesozoic-Tertiary forearc basin, southwestern Sacramento Valley, California. Geological Society of America 107 (1), 38-53.

Wakabayashi, J., Unruh, J.R., 1995. Tectonic wedging, blueschist metamorphism, and exposure of blueschists; are they compatible? Geology (Boulder) 23 (1), 85-88.

Wentworth, C.M., Blake Jr., M.C., Jones, D.L., Walter, A.W., Zoback, M.D., 1984. Tectonic wedging associated with emplacement of the Franciscan assemblage, California Coast Ranges. Field Trip Guidebook Pacific Section. Society of Economic Paleontologists and Mineralogists, vol. 43, pp. 163-173.

Westbrook, G.K., Ladd, J.W., Buhl, P., Bangs, N., Tiley, G.J., 1988. Cross section of an accretionary wedge; Barbados ridge complex. Geology (Boulder) 16 (7), 631-635.

Willett, S.D., Hovius, N., 1998. Active exhumation in Taiwan, extension or erosion? [abs.]. EOS (Transactions, American Geophysical Union) 79, 918.

Yu, S.-B., Chen, H.-Y., Kuo, L.-C., 1995. Velocity field of GPS stations in the Taiwan area. Tectonophysics 274, 41-59.

Yu, S.-B., Kao, L.-C., Hsu, Y.-J., Su, H.-H., Liu, C.-C., Hou, C.-S., Lee, J.-F., Lai, T.-C., Liu, C.-C., Liu, C.-L., Tseng, T.-F., 2001. Preseismic deformation and coseismic displacements associated with the 1999 Chi-Chi, Taiwan earthquake. Bulletin of Seismological Society America 91, 995-1012. 